\title{
The Biology of Colonial Hydroids. III. Influence of Temperature and Nutrition on Growth of Eirene viridula (Thecata-Leptomedusa: Capanulinidae)
}

\author{
M. Hündgen and M. Hartmann \\ Department of Zoology, University of Bonn, Poppelsdorfer Schloß, D-5300 Bonn 1, Federal Republic of Germany
}

ABSTRACT: The temperature tolerance of the hydroid Eirene viridula Peron and Lesueur lies within the range $11^{\circ}-31^{\circ} \mathrm{C}$ Colonies grow well between $19^{\circ}$ and $27^{\circ} \mathrm{C}$, and optimally at $23^{\circ} \mathrm{C}$, provided that they receive sufficient food (Artemia salina larvae) every second day. If fed less often, growth slows down. When fed at 16 -d intervals, phases of growth and regression alternate. After 29 days of starvation the colonies die.

\section{INTRODUCTION}

Due to the difficulties involved in studying the influence of external conditions on marine hydrozoans in the field, such effects are often examined by means of monofactorial analysis under laboratory conditions. The number of effective factors - which usually are interdependent and act jointly on the test organism - is relatively large. It is not surprising, then, that publications dealing with the responses of hydrozoans to temperature, food supply, light, salinity, pressure and dissolved gases are numerous (for reviews consult 'Marine Ecology', Volume I: Kinne, 1970, and Volume III: Kinne, 1977)

Eirene viridula can easily be cultivated in the laboratory (Hündgen, 1978), where it reproduces both sexually and asexually (Günzl, 1964; Bierbach and Hofmann, 1973; Germer and Hündgen, 1978); it has been employed as a sensitive indicator organism in tests of pollutant effects (Karbe, 1972). The present study on $E$. viridula is concerned with nutrition and temperature dependence of growth in secondary colonies which assume the form of a stolonial mat (Kinne, 1956) under laboratory conditions.

\section{MATERIALS AND METHODS}

Colonies of Eirene viridula were established on glass microscope slides standing vertically in 10-l aquaria. The culture medium used was filtered artifi- cial sea water with a salinity of $35 \% \mathrm{~S}$. The water was sufficiently well aerated so that it was not necessary to change it.

The experimental aquaria were kept in large tanks containing water maintained at $23^{\circ} \mathrm{C}$. Normally, the colonies were fed every $2 \mathrm{~d}$ by transferring the slides for $30 \mathrm{~min}$ to Petri dishes containing 3-d-old larvae of Artemia salina. The experiments were continued for $70 \mathrm{~d}$. Exceptions to these standard conditions are noted in the text.

\section{RESULTS}

Eirene viridula colonies increase by branching stolonial growth (Fig. 1). When tips touch other stolons, fusion may occur at points of contact. In this way a

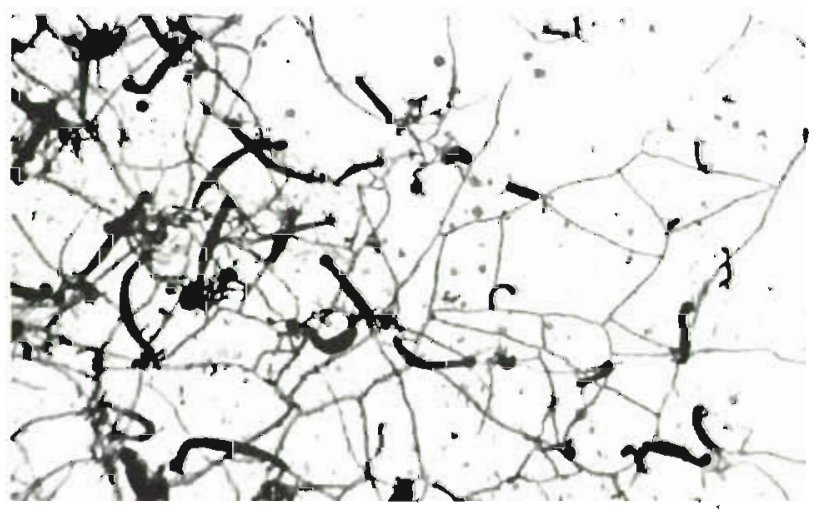

Fig. 1. Eirene viridula. Photograph of part of a living colony $(4.5 \mathrm{X})$ 
stolonial network is formed, coarse-meshed at first, and rapidly covering a large area. If the area of the substrate is limited, the continued formation of new branches reduces the mesh size of the hydrorhiza; reduction below a certain mesh size is followed by growth cessation.

The criterion for colony growth was the number of polyps (buds) per colony (Paffenhöfer, 1968). These were counted during feeding. At the beginning of each series of experiments, several-week-old colonies were reduced to 10 hydranths each. The hydrorhiza of all these colonies were selected so as to have principally the same pattern of branching at this stage, because one factor determining the growth rate of small colonies is the number of stolon branches present.

\section{Influence of Temperature}

To assess the effect of temperature on colony growth we transferred 4 colonies to aquaria in which the water temperature was gradually changed over a period of 24 h from $23^{\circ} \mathrm{C}$ to $4^{\circ}, 7^{\circ}, 11^{\circ}, 15^{\circ}, 19^{\circ}, 23^{\circ}, 27^{\circ}, 31^{\circ}$ or $39^{\circ} \mathrm{C}$. In water as cold as $4{ }^{\circ} \mathrm{C}$ or as warm as $39^{\circ} \mathrm{C}$ all hydranths died within the two following days; during this time most of the coenenchyma of the stolons had been broken down. Figure 2 summarizes the growth curves (obtained at $7^{\circ}-35^{\circ} \mathrm{C}$; each curve represents measurements conducted on four colonies).

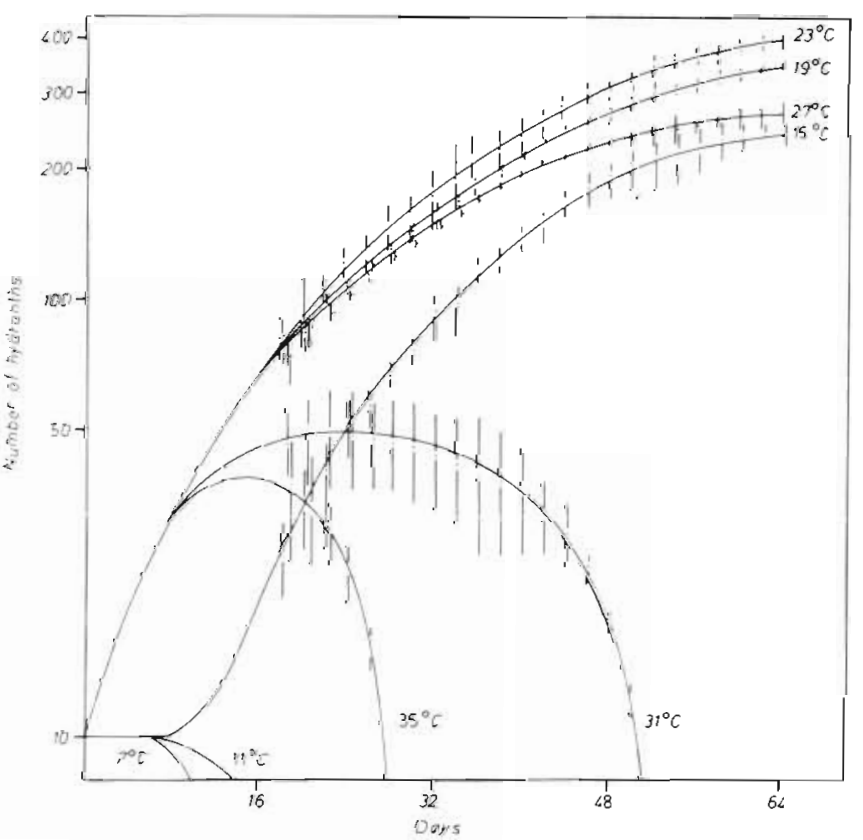

Fig. 2. Eirene viridula. Relation between number of hydranths and time of exposure (days) to the different temperatures indicated. Results of four experiments are combined in each curve. Points represent average measurements; vertical bars indicate ranges
In control experiments without temperature change $\left(23^{\circ} \mathrm{C}\right.$ in Fig. 2) colonies grew exponentially for $15 \mathrm{~d}$, then more slowly. Toward the end of the 70- $\mathrm{d}$ experiment these colonies attained their final size with ca 400 polyps. At this time, the slide serving as a substrate was completely covered by the colony. Colonies at $19^{\circ}$ and $27^{\circ} \mathrm{C}$ responded similarly, although the final polyp count was less: 350 and 270 polyps, respectively.

Even at high temperatures $\left(31^{\circ}\right.$ and $35^{\circ} \mathrm{C}$ in Fig. 2) initial growth was exponential, but then growth rates began to decrease drastically. At $31^{\circ} \mathrm{C}$ the number of individuals began to decrease from the 25th day on. All hydranths were resorbed after $55 \mathrm{~d}$. The coenosarc remained visible for a few more days, but in this condition could not be initated to form new hydranths by lowering the temperature to $23^{\circ} \mathrm{C}$. The situation was similar at $35^{\circ} \mathrm{C}$; however, decrease in growth began as early as the 15 th day, with resorption of all polyps after $30 \mathrm{~d}$.

When the optimal environmental temperature $\left(23^{\circ} \mathrm{C}\right)$ was lowered by more than $5 \mathrm{C}^{\mathrm{C}}$, growth stagnated. At $15^{\circ} \mathrm{C}$, growth stagnation turned, after about one week into a period of exponential growth $\left(15^{\circ} \mathrm{C}\right.$ in Fig. 2). Final colony size, with ca 240 polyps, was not appreciably smaller than at $27^{\circ} \mathrm{C}$. Reduction of the temperature to $11^{\circ}$ or $7^{\circ} \mathrm{C}$ caused immediate growth cessation followed after one week by colony regression. All hydranths were resorbed after $40 \mathrm{~d}$ at $11^{\circ} \mathrm{C}$, after only $15 \mathrm{~d}$ at $7^{\circ} \mathrm{C}$. The temperature range tolerated by Eirene viridula, then, lies above $11^{\circ} \mathrm{C}$ and below $31^{\circ} \mathrm{C}$. Growth is optimal at $23^{\circ} \mathrm{C}$ (Fig. 3).

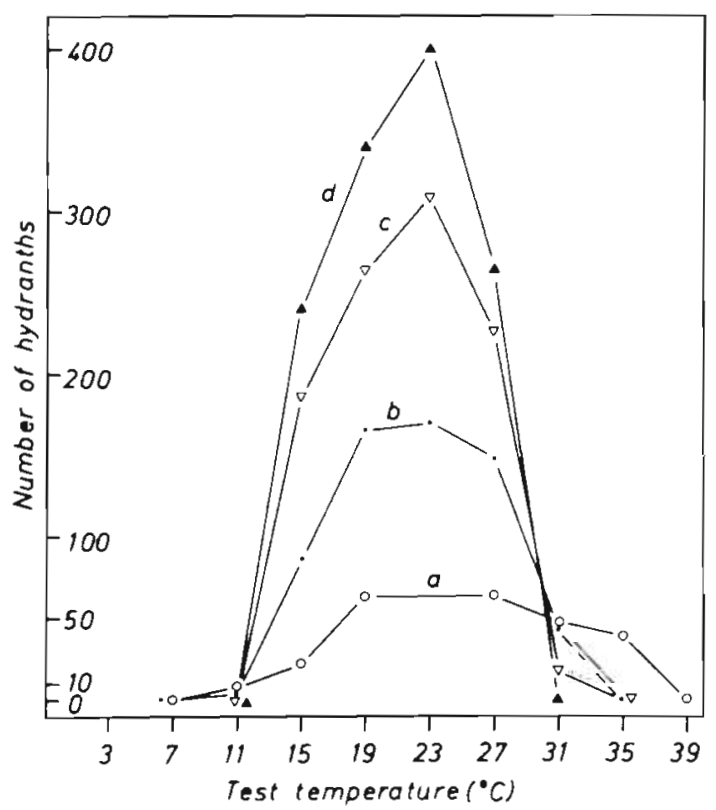

Fig. 3. Eirene viridula. Influence of temperature on growth (number of hydranths). Time of exposure to test temperatures: (a) $16 d_{i}$ (b) $32 d_{i}$ (c) $48 d_{i}$ (d) 64 d. Results of four experiments are combined in each curve 


\section{Influence of Food}

The effect of food supply on grow th was measured by feeding Eirene viridula colonies at various intervals, namely $2,4,8,16$ or $32 \mathrm{~d}$. Four colonies were studied under each condition. Daily feeding was not included in this programm, because pilot observations showed that growth rate did not differ from colonies fed at 2-d intervals. Figure 4 summarizes the results obtained. Colonies fed at short intervals (Fig. 4a), grew most rapidly. For these colonies average growth corresponds to the control curve obtained at $23^{\circ} \mathrm{C}$ (Fig. 2). Increase of the intervals between feedings to 4 and $8 \mathrm{~d}$ causes the growth curves to flatten (Fig. $4 \mathrm{~b}$ and $\mathrm{c}$ ). With feeding at 16-d intervals (Fig. 4d) the curves undulate: each feeding is followed by growth which continues for about one week and then gives way to regression. At the next feeding, regression is interrupted by a new growth phase. Because the increase in number of polyps during the growth phases is greater than the decrease during the phases of regression, there is a slight overall rise in the growth curve. The colonies do not survive a longer period ( $28 \mathrm{~d}$ ) of food deprivation.

\section{DISCUSSION}

Coelenterates are widely used as test material for laboratory experiments and their cultivation has received considerable attention (Loomis, 1954; Kinne, 1956, 1977; Crowell, 1957; Fulton, 1960, 1962, 1963; Bick, 1966; Wemer, 1968; Bierbach and Hofmann, 1973). In the experiments described here, we followed primarily recommendations by Fulton (1962).

Eirene viridula colonies grow less well after transfer to $27^{\circ} \mathrm{C}$ than at $23^{\circ} \mathrm{C}$. Similar findings have been reported by Bierbach and Hofmann (1973) for E. viridula, by Kinne (1956) for Cordylophora caspia and by Crowell (1957) for Campanularia flexuosa. Physiological competition between polyp and medusa buds, postulated by Günl (1964) to explain the lower rate of increase in Polyp number of Dipurenia reesi at increased temperatures, was not confirmed in our experiments; most of the medusae were formed in the first week of the experiment, during which growth at $19^{\circ}$, $23^{\circ}$ and $27^{\circ} \mathrm{C}$ was more or less the same (Fig. 2).

During the first days following a change in temperature, the colonies exhibit two types of response: initial growth stagnation $\left(15^{\circ}, 11^{\circ}\right.$ and $7{ }^{\circ} \mathrm{C}$ in Fig. 2) or exponential growth $\left(19^{\circ}, 27^{\circ}, 31^{\circ}\right.$ and $35^{\circ} \mathrm{C}$ in Fig. 2). However, the second type may also represent a 'successive response' (Kinne, 1956), in which adaptation lasts less than $2 \mathrm{~d}$ and thus was not detectable in our experiments.

Growth stagnation at the end of the experiment can

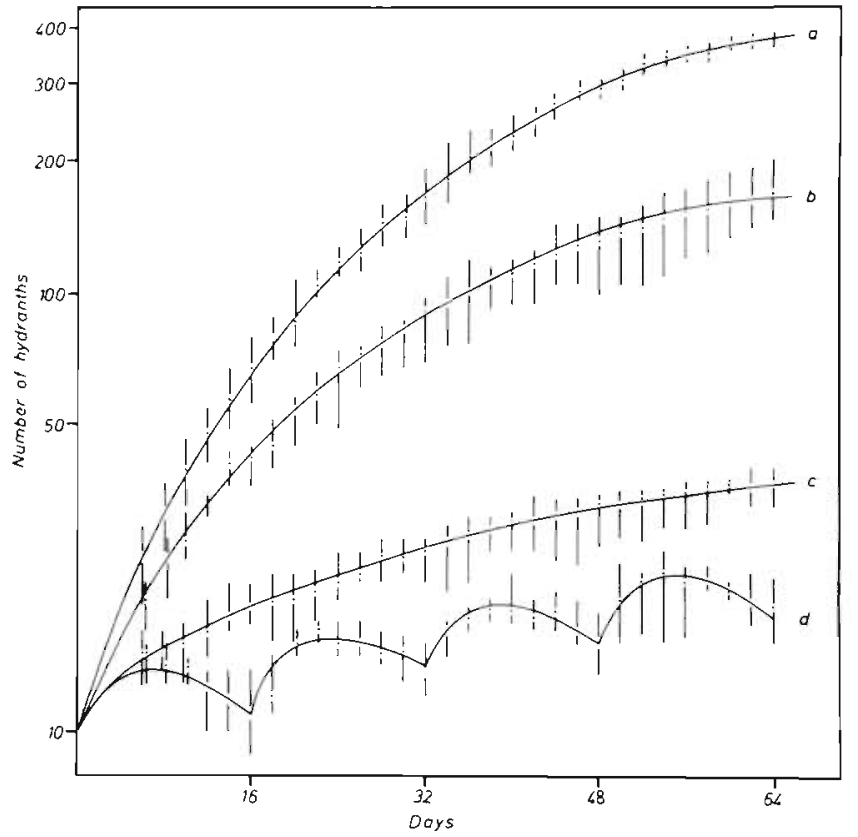

Fig. 4. Eirene viridula. Influence of feeding schedule (interval between feedings) on growth. Cultures were grown at $23^{\circ} \mathrm{C}$ and fed to saturation for $30 \mathrm{~min}$. The results of four experiments are combined in each curve. Points represent average measurements; vertical bars indicate ranges. Intervals between feedings: (a) $2 \mathrm{~d}$; (b) $4 \mathrm{~d}$; (c) $8 \mathrm{~d}$; (d) $16 \mathrm{~d}$; (e) $32 \mathrm{~d}$

be ascribed to the restricted size of the slide providing the substrate; after $70 \mathrm{~d}$ it was covered more or less completely by the stolon network of the Eirene viridula colony. When the experiments were continued beyond $70 \mathrm{~d}$, the cultures sometimes departed from their twodimensional form of growth building up in the third dimension.

Larvae of Artemia salina have proved a favorable food source for polyps (Loomis, 1954; Davis, 1971); the optimal amount to offer, however, can vary (Fulton, 1962). Whereas one feeding every second day produces optimal growth in Eirene viridula, Campanularia flexuosa grows best when fed twice a day (Crowell, 1957). With Hydra littoralis (Loomis, 1954) and Chlorohydra viridissima (Muscatine and Lenhoff, 1965), one feeding per day is sufficient for optimal growth. If feedings are more frequent than required for optimal growth, signs of regression eventually appear (Brinckmann, 1964; Davis, 1971). The duration of tolerable starvation periods also varies from species to species. As in the reef coral Favia fragum (Lewis, 1974), in Eirene viridula lack of food results in a reduction of hydranth size.

Acknowledgements. This work was supported by the Deutsche Forschungsgemeinschaft. We thank Professor Dr. N. Weissenfels for advice and discussion during the work. We are grateful for the technical assistance of Mrs. U. Müller, Mrs. I. Nüssle, and Mrs. B. Zarbock. 


\section{LITERATURE CITED}

Bick, H. (1966). Beobachtungen uber das Auftreten sexueller Prozesse bei Süßwasserpolypen und Ciliaten. Zool. Anz., $176,183-192$.

Bierbach, M. and Hofmann, D. K. (1973). Experimentelle Untersuchungen zum Stockwachstum und zur Medusenbildung bei dem marinen Hydrozoon Eirene viridula. Helgoländer wiss. Meeresunters., 25, 63-84.

Brinckmann, A. (1964). Observations on the biology and development of Staurocladia portmanni sp. n. (Anthomedusae, Eleutheridae). Can. J. Zool., 42, 693-705.

Crowell, S. (1957). Differential responses of growth zones to nutritive level, age, and temperature in the colonial hydroid Campanularia. J. exp. Zool., 134, 63-90.

Davis, L. V (1971). Growth and development of colonial hydroid in experimental coelenterate Biology. In $\mathrm{H}$. Lenhoff, L. Muscatine, and L. V Davis (Eds), Experimental Coelenterate Biology. University of Hawaii Press, Honolulu. pp. 16-36.

Fulton, C. (1960). Culture of a colonial hydroid under controlled conditions. Science, N.Y., 132, 473-474.

Fulton, C. (1962). Environmental factors influencing the growth of Cordylophora. J. exp. Zool., 151,61-78

Fulton, C. (1963). The development of a hydroid colony. Devl Biol., 6, 333-369

Germer, T. and Hündgen M. (1978). The biology of colonial hydroids. II. The morphology and ultrastructure of the medusa of Eirene viridula (Thecata-Leptomedusa: Campanulinidae). Mar. Biol., 50, 81-95.

Günzl, H. (1964). Untersuchungen über die Auslösung der Medusenknospung bei Hydroidpolypen. Zool. Jb. (Anat. Ontogenie Tiere), 81, 491-528.
Hündgen, M. (1978). The biology of colonial hydroids. I. The morphology of the polyp of Eirene viridula (Thecata Campanulinidae). Mar. Biol., 45, 79-92.

Karbe, L. (1972). Marine Hydroiden als Testorganismen zur Prüifung der Toxizität von Abwasserstoffen. Die Wirkung von Schwermetallen auf Kolonien von Eirene viridula. Mat Biol., 12, 316-328.

Kinne, O. (1956). Über den EinfluB des Salzgehaltes und der Temperatur auf Wachstum, Form und Vermehrung bei dem Hydroidpolypen Cordylophora caspia (Pallas). Athecata, Clavidae. Zool. Jb. (Abt. Allg. Zool. Physiol. Tiere), $66,565-638$.

Kinne, O. (1979). Temperature: animals: invertebrates. In O. Kinne (Ed.), Marine Ecology, Vol. I, Environmental Factors, Part 1. Wiley, London. pp. 407-514.

Kinne, O. (1977). Cultivation of animals: research cultivation. In O. Kinne (Ed.), Marine Ecology, Vol. III, Cultivation, Part 2. Wiley, Chichester. pp 579-1293.

Lewis, J. B. (1974). Die Bedeutung von Licht und Nahrung für das Wachstum der Riffkoralle Favia fragum. J. exp. mar. Biol. Ecol., 15, 299-304.

Loomis, W. F. (1954). Environmental factors controlling growth in hydra. $J$. exp. Zool., 126, 223-234.

Muscatine, L. and Lenhoff, H. M. (1965). Symbiosis of Hydra and algae. II. Effects of limited food and starvation on growth of symbiotic and aposymbiotic Hydra. Biol. Bull mar. biol. Lab., Woods Hole, 129, 316-328.

Paffenhöfer, G. A. (1968). Nahrungsaufnahme, Stoffumsatz und Energiehaushalt des marinen Hydroidpolypen Clava multicornis. Helgoländer wiss. Meeresunters., 18, 1-44.

Werner B. (1968). Polypengeneration und Entwicklungsgeschichte von Eucheilota maculata (Thecata-Leptomedusae). Helgoländer wiss. Meeresunters., 18, 136-168. 